\title{
CONSUMER BUYING PREFERENCE BASED ON GREEN MARKETING AND GREEN PRODUCT DEVELOPMENT
}

\author{
V. Sai Prasanth*, Prof. M. Jyothsna, Dr.N.Aruna Kumari
}

Research Scholar, GITAM (Deemed to be University)Vishakhapatnam, AP, India Head Of Marketing, GITAM (Deemed To Be University), Vishakhapatnam, AP, India

Professor of Chemistry and Environmental Science, A.P., India

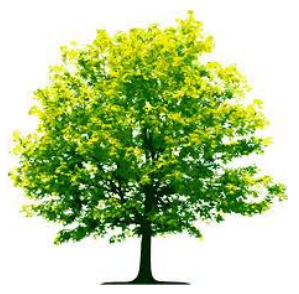

Keywords: Green marketing, green product development, expenditure, environmental benefits.

\begin{abstract}
A B S T R A C T
In todays global scenario ecological issue is getting worse, the consumers' are more concerned about the environmental protection, with the change in consumer buying approach in the steering of a immature lifestyle. As a consequence, firms are implementing potential ecological approaches in the green market industry. Green marketing and green product development are constructive techniques, which are applied by firms to raise competitive advantages and gain the satisfaction of consumers in order to accomplish the firm's mission and vision. Green marketing and green product development have a variety of benefits to firms in terms of promoting the sustainable environmental benefits and to increase the awareness of brand image of the house. This work concentrates on the concept of green marketing and green product development, the different consumer consumption in regards to green marketing and green product development, and lastly examines the problems that firms have faced when they have neglected to go through green marketing and green product development.
\end{abstract}

Citation: V. Sai Prasanth, M. Jyothsna, N.Aruna Kumari (2018). Consumer Buying Preference Based On Green Marketing And Green Product Development. International Journal of Advanced Multidisciplinary Scientific Research (IJAMSR ) ISSN:2581-4281 Vol 1, Issue 7, September, 2018, \#Art.719, pp 89-98

\section{Introduction}

According to Yakup and Sevil (2011), from the beginning of the 1980s, there have been ecological issues such as global warming, the greenhouse effect, pollution, and climate changes which are directly related to industrial manufacturing and this will continue to affect human activities. Referable to the growth of environmentalism, which has ruled the world, there has been a boost in consumer concern with regards to environmental security and great demand for green products. Hence, most houses have begun to apply the 
green marketing and green product development strategies that can protect the environment while fulfilling consumers' preferences in order to produce high profits in commercial enterprises. Most of the firms were using green marketing as a sub form of their marketing structure as good as attempting to develop green products that could assist with the growing environmental problems. There are organizations implementing strategies which direct to solve ecological issues and construct up the long term interest to consumers. The advantages of green marketing and green product development, the relationship between green marketing and green product development towards the consumers buying approach and the problems are included in this research report.

\section{Aim of the Study}

The aim of this clause is to understand Consumer Buying Preference Based on Green Marketing and Green Product Development also to evaluate the steps adopted by the Indian companies for green marketing in their core business values.

\section{Research Methodology}

The present work is exploratory in nature to offer a clear guidance for empirical inquiry. It is also descriptive where the focal point is on fact-finding investigation with adequate reading. For this purpose secondary data were collected through newspapers, mags, books, journals, conference preceding government reports and web sites.

\section{Literature Review}

Green marketing also refers to an establishment that puts its efforts into advertising, pricing, and distributing products with eco-concerns (Sarkar, 2012).

Different authors provided different meaning of green marketing. According to Chaudhary, Tripathi, and Monga (2011) the term of "green marketing" first discovered in the former 1970s. American Marketing Association (AMA) defined it as "ecological marketing".

Green marketing consists of a broad scope of job activities which intends to satisfy customers' needs and wants, as well as diminish the negative impacts on the natural environment (Tiwari, Tripathi, Srivastava, \& Yadav, 2011).

American Marketing Association (AMA) said that the green marketing approach is the merchandising of merchandise that are chiefly focused on environmental safety; it integrates business activities which consist of packaging modification, production process, and green advertising (Yazdanifard \& Mercy, 2011).

Green marketing is likewise distinguished as any promotional activity which plays up the environmental ethics as business fundamentals and it can perceive an advantage of changing consumer behavior towards a brand (Peattie \& Charter, 2003). 


\section{International Journal of Advanced Multidisciplinary Scientific Research (IJAMSR) ISSN:2581-4281}

\section{Green Marketing}

Granting to the American Marketing Association, green marketing is the merchandising of merchandise that are presumed to be environmentally safe. Thus, green marketing incorporates a wide scope of actions, including product change, changes to the production process, packaging changes, as well as modifying advertising. Yet defining green marketing is not a simple task where the several meanings intersect and contradict each other; an example of this will be the existence of changing social, environmental and retail definitions attached to this condition. Other similar terms used are Environmental Marketing and Ecological Marketing. So "Green Marketing" refers to holistic marketing concept wherein the production, marketing consumption a disposal of merchandise and services happen in a way that is less prejudicial to the environment with growing consciousness around the implications of planetary heating, non-biodegradable solid waste, harmful impact of pollutants etc., both marketers and consumers are getting more and more sensitive to the need to switch into green products and services. While the switch to "green" may look to be expensive in the short term, it will definitely prove to be indispensable and advantageous, cost-wise too, in the long run.

\section{Green Product Development}

The efficient green product development played an important role in the green marketing strategy. It can help the firms and economies move swiftly towards a sustainable environment. Green product development emphasizes "end of pipe technology" where the firms are aware of ecological issues through the cognitive operation of production and product design (Chen,
1994). In particular, Chen (2001) revealed that the product designed to downplay the utilization of nonrenewable resource, avoiding toxic materials, and renewable resource during its whole lifetime-cycle would be the most efficient mode to display green technological development. Most firms acknowledged integrating environmental laws and rules such as Registration, Evaluation and Limitation of chemical substances into the operation of green product development; hence it can cut down the hazard risk to the environment while satisfying the consumers' expectation on green consumption (Tsai, Chuang, Chao, \& Chang, 2012). The Green product development encompasses food safety concern, label, and price; it may affect the consumers' purchasing behavior of green products (Bing, Chaipoopirutana, \& Combs, 2011).

\section{Consumer Buying Approach}

Consumer behavior has been illustrated as the natural processes of consumers who identify a need or want, researching for information, buying, using, and giving feedback on the products and services in order to satisfy their desires (Vyas, 2009). In the 20th century, most markets clearly understand the actual behavior, genes, and aims of the consumers' buying approach by aiming for the utilization of environmentally friendly marketing. Due to the detrimental impacts on the natural environment, green marketing activities have been a popular tool that used by many firms, and these events caused a shift in consumers' buying approach towards green products (Cohen, 1973). Consequently, most consumers have adapted to the concept of "green consumers" who were cognizant of the importance of conservation and protection of the natural surroundings as well as seeking for eco-friendly products as they 


\section{International Journal of Advanced Multidisciplinary Scientific Research (IJAMSR) ISSN:2581-4281}

demand of green consumption grows (Peattie, 2001). Further to this information, Boztepe (2012) emphasized that the green consumers would stop consuming any harmful product which may bear on their health, involves torture of animals and does harm to the environment during the output process, disposition or use. A portion of marketers may take to enhance the consumers' consciousness of environmental problems by using marketing ploys to get them taken in social charities which motivate the consumers' to move from established products to eco-friendly products (Golkanda, 2013).

\section{Advantages of Green Marketing and Green Product Development}

While the firms use green marketing in the modification of business and implement green product development, it can reduce operating and production costs in the long term. There are firms who have adjust up the solar panel technology in their modification of business; it can be an investiture on the cost benefits (Ottman, Stafford, \& Hartman, 2006). The firms can practice the green product development to standardize the product change and make do the new materials with environmental concerns, thus, decrease the negative impacts on human health and the environment (Tsai, Chuang, Chao, \& Chang, 2012). Furthermore, the firm can attempt to improve the product design; it can cut down the amount of material that will need to be disposed of and try to determine whether it will be environmentally harmful. In this operation, it can likewise be determined whether it is potential to cut the material usage in order to enhance recyclability and reusability (Polonsky, 1994). According to Ankit and Mayur (2013), most marketers use green advertising with pollution free messages to draw consumers' attention; it can heighten their knowledge of the products and ecological matters. Indeed, the firms can increase their corporate eco-centric image and it drives the consumers' perception towards the house. Substantially, the firms have generated the revenue and developed a new approach to international markets; it can increase the competitive advantages of the firms in order to achieve the stabile position of the houses. In summation, the employees will possess more confidence and satisfaction towards the stabile position of the house, thus the productivity of the firm will be increased (Pierce, Rubenfeld, \& Morgan, 1991). Ultimately, the greatest chance for firms which are giving the green marketing is that houses can obtain grants and loan from the government to arrange up the technology for the development (Ottman, 2011). It could be stated that firms receive a chance to behave in an environmentally responsible manner and use the financial resources to establish the firms' innovative environmental products and engineering sciences in order to reach the long term profitability and as well as ensuring environmental sustainability.

\section{The Relationship between Green Marketing and} Consumer Purchasing Behavior

The marketing mix includes product, price, promotion, and place (4P's). The ingredients of marketing mix in green marketing are essential for marketers to use to reach the firm's objectives. According to Young, Hwang, McDonald, and Oates (2010), there are 30\% of consumers said that green products must be energyefficient, aid in water conservation, be safe in regards to the environment during the process of manufacture, usage and administration. The hazardous content of a product may affect the consumers' purchasing decisions; 


\section{International Journal of Advanced Multidisciplinary Scientific Research (IJAMSR) ISSN:2581-4281}

hence the manufacturers tend to create the products which are eco-friendly to satisfy the need of green consumers. There are international firms that use green marketing to make hybrid cars that purposely aim to balance the demand of the firm's revenues with the firm' responsibility to reduce the environmental impacts of contamination. For example, Toyota produces the Prius, which offers several desirable benefits for consumers and the natural environment (Halbright \& Dunn, 2010). The Prius has an environmental engineer which includes emission-reducing gasoline, thus it can decrease the emission of carbon dioxide and nitrogen dioxide into the atmosphere; lower emissions will result into a positive impact on the environment, lowering the pollution given off into the air. If enough people were to buy a Prius, it could be contended that it would take in a big impact on global warming, but the sale of one of these autos will not resolve the problem (May, Cheney, \& Roper, 2007). Referable to the monetary value of fuel increasing, Toyota produced Prius, which can lay aside the cost of fuel, which can be a plus factor if many consumer's opinions. Consumers who experience strong environmental concerns, such as counting the environmental claims and safety to the environment, will likely result in ecologically conscious buying and use of a hybrid car (Balderjahn, 1988). It could be said that Prius satisfy the need of the consumers for an ecofriendly product. As a result, the consumers expressed great satisfaction towards the eco-friendly product; it builds up a positive judgment towards Toyota Corporation and the consumers were likely to trust the dependability of the Toyota's products.

Succeeding, the cost of a product must be varies to the personal income of the consumer. Most of the firms are using, low cost strategies to encourage the consumers to purchase eco-friendly merchandise. In this state of affairs, the firms create a competitive advantage in the market place in order to increase the business development. If the cost of a product is higher; the houses have to distinguish the value of the premium product in the terms of quality, specification and appearance (Chandra, 2009). Starbucks is a global firm that is trading at a premium and ethically sources its products which indicates they are dedicated to being environmentally responsible, as well as downplaying the environmental footprints by reducing material waste and building green and energy-efficient stores ("Global", 2014). Additionally, Coffee and Farmer Equity (C.A.F.E) Practices awarded Starbucks' coffee; the certification of coffees meets the consumers' expectations, but also helps improving in the protection of the environment ("Global", 2014). The consumers who are of a low-price sensitivity are willing to pay more on the product than the variation of price, also perceive that the value of the eco-friendly product more than the conventional price for a product in the regular terms of monetary value and quality (Eze \& Ndubisi, 2013). Thereby, the consumers who are willing to yield premium for Starbucks' products because the green brand equity of Starbucks is responding to climate change and being proactive in its attitude towards pollution issues. Furthermore, the consumers express warmly towards the green products and this will convey a positive outcome to the brand equity and increase the probability of purchases in the future (Chen, 2010).

Green advertising is a promotional strategy which leaves the marketers to employ singular and creative ways to raise the merchandise. The strong, convincing message from the green advertisements causes the consumers to focus on the topics being explained to them, as well as 


\section{International Journal of Advanced Multidisciplinary Scientific Research (IJAMSR) ISSN:2581-4281}

influence consumers' purchase behavior in regards to the firm's image (Zinkhan \& Carlson, 1995). Sharma (2011) discovered that there are three criteria of a green advertisement which are the advertisement begins with educational content that concern for the environment, the advertisement states the firms have changed the procedures of production in order to promote a green lifestyle and the advertisement addresses a firm's image of environmental responsibility. According to Laric and Lynagh (2010) stated that Samsung has an environmental program named as "Planet First" which was purposely introduced to balance the demand for cutting edge technology with the responsibility of diminishing the environmental impacts in order to promote a green way of life. Moreover, Samsung delivered their responsibility of green commitment and green messages to the consumers through the Samsung web site and ESPN Magazine, hence it can promote the firm's dedication to sustainability (Laric \& Lynagh, 2010). In this state of affairs, the consumers from emotions when exposed to green advertisement which affects their attitude and perception towards the green advertisement and beliefs around the steady image (Cox, 2008). In summation, the environmental claims from the advertisement will direct the consumers to behave in a positive ecological manner and it will influence their purchase intention of that product (Davis, 1993).

In the end, the firms deliver to furnish the product at a strategic position that is convenient for consumers to access so that it may influence the purchase decision of consumers. Most marketers successfully positioned new green products in the marketplace as long as the location was more salient than that of a company from its rivals. For instance, Starbucks builds the green concept in its stores globally in order to integrate the approach of cutting down the environmental risk to create the sustainability of the firm ("Global”, 2014). The keyword of "Place" in marketing mix also refers to physical distribution which is a circle of business activities that requires the movement of storing and shipping finished products while going forward to maintain concern with the environmental responsibility of the firm. Arseculeratne and Yazdanifard (2014) stressed that green distribution focuses on safety precautions and reduces environmental damages during the operation of rendering merchandise. For instance, cutting the thickness of packaging can reduce the fuel that is used up by trucks and it can shorten the negative impacts on the roads. B\&G focused on the "centralized distribution" program and the establishment of policies that convey environmental benefits such as reducing the frequency the number of vehicle drives as easily as the decrease in fuel consumption, which lowers the problem of pollution, hence the firm has been awarded with environmental excellence (Peattie \& Charter, 2003). Mohr, Webb, and Harris (2001) suggested that there are empirical researches that have indicated that high corporate social responsibility levels of the firm positively influence the consumer's buying decision. The green commitments and environmental concerns of the firm that caused the consumers established positive evaluation of the firm in the consumers' perception, therefore $B \& G$ have a great value positioning among the consumers. Due to this issue, the demand from consumers towards B\&G's product increased and the output of the firm will increase in the long run. 


\section{International Journal of Advanced Multidisciplinary Scientific Research (IJAMSR) ISSN:2581-4281}

The Relationship between Green Product Development and Consumer Purchasing Behavior:

According to Song and Parry (1997) there are eight levels of product development which are; idea generation and screening, business opportunity analysis, expert execution, product testing and product commercialization. Likewise, green product development consists of eight phases of product development and pollution analysis, which are the procedures to identify the environmental risks, identify the sources of pollution during the product's life cycle and minimize the environmental impacts that have been found (Bhat, 1993). Fujitsu Group developed "Green Product Evaluation Standards" criteria into the environmentally friendly products that it produces. This procedure is projected to help preserve natural resources and reduce chemical emission in order to maintain low eco-foot printing standard norms and increase productivity of the firm ("Green Products", 2014). Furthermore, the Fujitsu Group established recycling technology that used biodegradable plastic integrated with notebook computers. Fujitsu's notebook computers promote energy-efficiency and it has lived up to the consumers' needs and wants by supplying a computer that tracks all facets of consumer criteria ("Green Products", 2014). It was demonstrated that consumers have become sensitive to the ecological issues, and this has to be incorporated into green products for them to be deemed successful in their relevant markets. Clients who are touched with the environmental impact of products are likely to purchase green products where they are usable to them; it is also probable that they will be more willing to pay a higher toll for such products if they are deemed to be better for the environment (Laroche, Bergeron, \& Barbaro-Forleo, 2001).

One of the significant factors of green product development is the promotion of eco-labels on the merchandise. Eco labeling is an effective tool which can furnish the information on two main functions which is the information function that speaks the quality characteristics of the tangible product and the value function which provides the corporate environmental image of the firm (Sammer \& Wustenhagen, 2006). In the eyes of consumers, eco-label is an invention. The display of the data on the product has to be reliable so that the labels provide functional instructions and meaning to consumers, as it addresses an important function in consumer buying decision (Pedersen \& Neergaard, 2006). Rashid (2009) found out that the consumers who have environmental knowledge enable them to distinguish the products which are more environmentally preferable in the market, thus eco-labels were initiated to promote environmental consumerism. Moreover, the eco-label on the products creates a distinct image to the consumers' cognition and the placement of a product make up the consumers' first choice of purchase (Purohit, 2012). One of the examples of eco-label is Nordic Swan that related to vitality and water preservation, this credible environmental information positively influences the consumers' purchase intention toward a brand and it will increase the sales volume of the firm (Bjorner, Hansen, \& Russell, 2004)

\section{Problems While Going Green}

There are firms who apply green marketing to accomplish their mission and vision, but there are a number of firms who fail to carry out green marketing successfully, whereby the marketers did not structure the green marketing strategy appropriately that caused potential problems to come up. Thus, the firms should 


\section{International Journal of Advanced Multidisciplinary Scientific Research (IJAMSR) ISSN:2581-4281}

obey the laws and rule according to the FTC's guidelines in society to not mislead any consumers or industry members (Chowdhury \& Dasani, 2013). The firms have to perform with the FTC's guidelines which describe the environmental benefits, providing environmental criteria, explaining the way the environmental benefits are achieved, developing the comparative advantages, keeping off the hazardous content and expressing the environmental claims in picture or text (Polonsky, 1994). Some of the houses have limited scientific and business technology knowledge, which causes many incorrect business decisions to be made which can conduct to further danger towards the surroundings. For example, some firms used DME (dementia ether) as an aerosol propellant; it will also make for a negative impact to ozone layer (Fleisch, Basu, Gradassi, \& Masin, 1997). Most of the consumers at the time were unaware of the serious ecological issues had been brought in to effect with the purpose of the merchandise. Since this incident, it is potential that the consumers will not pay attention to the environmental claims from the green advertisement for these products (Golkonda, 2013). Chang (2004) observed that the ambiguous environmental statement from the green advertisement did not strongly illustrate the eco-centric image of the house, thus the advertised product fail to draw consumers' attention. In results, the consumers perceived that the carrying out of the green products that were manufactured with recycle materials or remanufactured products have poor execution than the conventional products and the consumers are not willing to buy green products for a higher price (Michaud \& Llerena, 2011). Referable to the lack of knowledge of the consumers, the consumers will not trust the ecolabels; it may ensue in the consumers ignoring the Eco labeling (Cherian \& Jacob, 2012).

\section{Overview}

The research of this paper purports to examine how the concept of green marketing and green product development and how it determines the purchasing approach of consumers. This research report is significant because the world is today confronted with environmental destruction and contamination levels are growing worse day by day, which will finally contribute to the continued worsening of human spirit. Green marketing is a strategy that addresses the business of promoting and maintaining the natural environment which can benefit the firms, consumers and the environment while the green product is produced. Most houses have begun to practice the concept of green marketing and green product development in the day to day business operations to create eco-friendly products in order to satisfy the consumers' wants and demands. Beyond this, there is a shift in consumers' behavior towards a greener life style; it is recognized as the "green consumer". While the firm meets the demand of consumers, it caused the production of the firm to increase. The eco-centric image of the house realizes a profound impression of in consumers' cognition; hence the firm can find greater satisfaction and faith from consumers easily. In results, the firm which behaves in an environmentally responsible manner is likely to achieve long-term profitability and environmental sustainability.

As the environmental issues have worsened, most international firms have begun to apply the marketing mix concept in green marketing which can accomplish the firm's mission and vision in short periods. The houses have to identify the customers' environmental needs and produce green products which pass the quality 
expectations of clients. Moreover, firms have to insure that the value of the green product on the aspect of performance, design, and visual appeal must exceed the cost of the green product. Most firms used green advertisement as a promotional scheme which can educate consumers about the path of protecting the environment and it also can establish the eco-centric image of the house. Additionally, the location of the funds must be convenient for the consumers to access. The firms have to cut the environmental impacts while distributing and transmitting the new materials or completed goods. Eco-labels have been a particularly significant event within the green product development, it often provides clients with a dependable meter reading of a product's social and ecological certification. The more consumers willing to ante up for a green product, the more firms are able to follow the changes in demands and conduct of the consumers.

Nevertheless, there are firms that implement green marketing and green product developments inappropriately and it contributes to the occurrence of problems that may burden the firm in the hereafter. For instance, the low perceived credibility of ecological claims in a green advertisement may cause the consumers to accept a negative attitude towards the firm when they run to purchase a similar product in the future - if they are not deterred completely in the first example. Consequently, the marketers should structure their green marketing strategy with outstanding caution and precision before they carry out the product into their firm. The goal of strategic planning can keep consumers retention; as well as minimizing environmental impacts in order to attain long term profitability and increase.

\section{Conclusion}

As the rising fear of ecological issues had begun to form, society and the government have started to be aware about these subjects and begin to create changes to contain the negative impacts of these troubles. Green marketing and product evolution have been deemed the best ways forward for a business to be able to adapt to new rulings from the government, and also to be able to comply with the behavior of consumers from field studies into the wants and needs. The firms believed that the ideas of green marketing such as enforcing a green supply chain, green product design, publicity, pricing and promotion are beneficial to society and the surroundings; and so it has assumed precedence over conventional marketing initiatives. Furthermore, the firms should present notable efforts to its customers in a way that expresses the house is actively attempting to lessen its environmental risk. In closing, implementing green marketing and green product development strategy is not sophisticated, but instead a relative concept that consistently differs over the time. 


\section{International Journal of Advanced Multidisciplinary Scientific Research (IJAMSR) ISSN:2581-4281}

\section{References}

1) Ankit, G., \& Mayur, R. (2013). Green marketing: Impact of green advertising on consumer purchase intention. Advances in Management, 6(9), 14-17. Retrieved from http://ezproxy.snhu.edu/login?url=http:// search.proquest.com/docview/143735596 2 ? accountid $=3783$

2) Arseculeratne, D., \& Yazdanifard, $R$. (2014). How green marketing can create a sustainable competitive advantage for a business. International Business Research, 7(1), 130-137. Retrieved from http://ezproxy.snhu.edu/login?url=htt p://search.proquest.com/docview/147 7173969 ? accountid $=3783$

3) Balderjahn, I. (1988). Personality variables and environmental attitudes as predictors of ecologically responsible consumption patterns. Journal of Business Research, 17(8), 51-56.

4) Bhat, V. N. (1993). A blueprint for green product development. Industrial Management, 35(2), 4. Retrievedfrom

http://ezproxy.snhu.edu/login? url=http://search.proq uest.com/docview/211627884? accountid $=3783$

5) Bing, Z., Chaipoopirutana, S., \& Combs, H. (2011). Green product consumer buyer behavior in China. Journal of Business Research,4(1),5571.Retrievedfromhttp://ezproxy.snhu.edu/login?url $=h$ ttp://search.proquest.com/docview/

1153781690? accountid $=3783$

6) Bjorner, T. B., Hansen, L. G., \& Russell, C. S. (2004). Environmental labeling and consumers' choice-an empirical analysis of the effect of the Nordic Swan. Journal of Environmental Economics and Management, 47(3), 411-434. Retrieved from http://dx.doi.org.ezproxy.snhu.edu/10.1016/j.jee m.2003.06.002

7) Boztepe, A. (2012). Green Marketing and its impact on consumer buying behavior. European Journal of Economic and Political Studies, 5(1). Retrieved from http://ejeps.fatih.edu.tr/docs/articles/146.pdf

8) Chan, R. Y. K. (2004). Consumer responses to environmental advertising in china. Marketing Intelligence \& Planning, 22(4),427437.Retrievedfromhttp://ezproxy.snhu.edu/login?url =http://search.proquest.com/docview /213115007? accountid $=3783$

9) Chandra, M. (2009), Green marketing: A new dimension in the marketing field. Economic Challenger. Retrieved from http://search.proquest.com/docview/ 216798453 ? accountid $=3783$
10) Chaudhary, B., Tripathi, S., \& Monga, N. (2011). Green marketing and CSR. International Journal of Research in Finance \& Marketing, 1(6). Retrieved from http://www.euroasiapub.org/IJRFM/Oct201 1/5.pdf

11) Chen, C. (2001). Design for the environment: A quality-based model for green product development. Management Science, 47(2),250 263.Retrievedfromhttp://ezproxy.snhu.edu/login ?url=http://search.proquest.com/docview/ 213161386 ? accountid $=3783$

12) Chen, J. Y. C. (1994). The economic impacts of green product development. Retrievedfrom http://dspace.mit.edu/bitstream/handle/1721.1/35382/3 0962445.pdf? sequence $=1$

13) Chen, $Y$. (2010). The drivers of green brand equity: Green brand image, green satisfaction, and green trust. Journal of Business Ethics, 93(2), 307-319. Retrieved from http://dx.doi.org/10.1007/s10551-0090223-9

14) Cherian, J., \& Jacob, J. (2012). Green marketing. A study of consumers' attitude towards environment friendly products. Asian Social Science, 8(12). doi:10.5539/ass.v8n12p117

15) Chowdhury, S., \& Dasani, L. (2013). “Green marketing- A new corporate social responsibility". ASM's International E-Journal of Ongoing Research in Management and IT. Retrieved from http://www.asmgroup.edu.in/incon/publication/i ncon13-mkt-022.pdfCohen, $M . \quad R . \quad$ (1973). Environmental information versus environmental attitudes. Journal of Environmental Education, 3(2), 5-8.

16) Cox, M. J. (2008). Sustainable Communication: A Study of Green Advertising and Audience Reception within the growing arena of Corporate Social Responsibility. Case Study: British Petroleum. Earth \& E-nvironment, 3, 32-51. Retrieved from http://homepages.see.leeds.ac.uk/ lecac/ejournal/ 3,32-51.pdf

17) Davis, J. J. (1993). Strategies for environmental advertising. The Journal of Consumer Marketing, 10(2), 19. Retrievedfromhttp://ezproxy.snhu.edu/logi n? url=http://search.proquest.com docview/220123743? accountid $=3783$ 